\title{
Adopting a New Religion: The Case of Protestantism in 16th Century Germany
}

\author{
Davide Cantoni* \\ Universitat Pompeu Fabra
}

March 2010

\begin{abstract}
Using a rich dataset of territories and cities of the Holy Roman Empire in the 16th century, this paper investigates the determinants of adoption and diffusion of Protestantism as a state religion. A territory's distance to Wittenberg, the city where Martin Luther taught, is a major determinant of adoption. This finding can be explained through a theory of strategic neighbourhood interactions: in an uncertain legal context, introducing the Reformation was a risky enterprise for territorial lords, and had higher prospects of success if powerful neighbouring states committed to the new faith first. The model is tested in a panel dataset featuring the dates of introduction of the Reformation.
\end{abstract}

Version: 1.0.1

Keywords: Protestantism, State religions, Germany, Spatial adoption of policies

JEL Classification: $\mathrm{N}_{34}, \mathrm{Z}_{12}, \mathrm{R}_{3} 8$

\footnotetext{
*Universitat Pompeu Fabra, Departament d'Economia i Empresa, Ramon Trias Fargas 25-27, 08005 Barcelona (Spain), and Barcelona GSE. Email: davide. cantoni@upf .edu. I thank Antonio Ciccone, Ruixue Jia and Joachim Voth for helpful comments, and Regina Baar-Cantoni and Eike Wolgast for expert counseling on the history of German Reformation. Katharina Kube provided outstanding research assistance.
} 


\section{Introduction}

Starting with Max Weber's (1904/05) famous inquiry on the "Protestant Ethic and the Spirit of Capitalism," religion has widely been seen by social scientists as one of the cultural traits most likely to influence economic outcomes. The findings about any direct effects of Protestantism on economic growth are unclear at best (Delacroix and Nielsen, 2001; Cantoni, 2010). However, economists have explored the connections and found robust correlations between religious denominations, in particular the Protestant one(s), and economic attitudes (Guiso et al., 2003), political institutions (Woodberry, 2010), literacy (Becker and Wößmann, 2009), social ethics (Arruñada, 2010), or even the introduction of Western knowledge in China (Bai and Kung, 2011).

Where religious denomination is, for most of the population, a variable of choice, and is often subject to changes over an individual's lifetime (such as in the United States), any observed correlations between faith and socioeconomic outcomes is difficult to interpret in a causal way. Individuals will potentially select into a religious group that espouses their own pre-existing attitudes, beliefs, or views of the world. On the other hand, in many other parts of the world religious denomination is a highly persistent variable, which is transmitted across generations. For example, in all likelihood a European (if she has not selected out of religion completely) is likely to have the same religion that her forefathers had in the 19th or 18th century, or even earlier. In such a context, understanding why certain regions have, at one point in time, decided to embrace the Protestant Reformation or to remain Catholic is of peculiar importance in order to disentangle the causal effect of religious denominations from other cultural traits or socioeconomic unobservables.

The Holy Roman Empire in the 16th century provides a suitable setting to observe such religious choices across a variety of territories, within a limited time frame. The 
Empire was a loose confederation of hundreds of small and large territories of different kinds: secular principalities, ecclesiastical states such as prince-bishoprics, or city-states such as the Free Imperial cities. Between the emergence of Martin Luther's critique of the Church in Rome (1517) and the normal year set by the Peace of Westphalia (1624), many of these territories effectively chose to adopt the new, Protestant faith, and made this choice binding for all their subjects. Other territories chose to remain Catholic instead. This paper focuses on the eventual decision made by the princes of the Holy Roman Empire; through a provision of the Peace of Augsburg (1555), the rulers' choices were binding for their subjects.

The high fractionalization of the Holy Roman Empire provides the advantage of yielding many more units of observation than if the question was asked in other contexts, e.g. for the other nations of Europe. There, the choice of whether to adhere to the Protestant teachings or stay with the Catholic Church was made at the level of sovereigns (the Kings of France, England, or Castile and Aragon, e.g.) whose realms approximately correspond to the borders of their present-day successor states. One would thus be left with only a handful of observations, encompassing the highly idiosyncratic biographies of monarchs.

Which were the determinants of these denominational choices? In a cross-section of 103 territories, this paper finds that three variables are strong and consistent predictors of the adoption of Protestantism: the nature of a territory's rule (ecclesiastical territories were less likely to become Protestant), its size (larger territories were more likely to remain Catholic), and its geographic location (territories more distant from Wittenberg, Martin Luther's town, were less likely to become Protestant). On the other hand, a comparatively stronger presence of the Church at the beginning of the 16th century does not appear to tilt the balance in either direction. 
A spatial panel model, featuring the dates of introduction of the Reformation, is used to understand the dynamics of the diffusion of the new creed and the role of a territory's distance to Wittenberg. Distance to Wittenberg does not appear to affect the timing and likelihood of adoption of Protestantism because of costs of spreading information across space. Instead, the findings are consistent with a theory of strategic neighbourhood interactions: in an unsafe institutional setting (for large parts of the 16th century it was unclear whether the adoption of Protestantism would be tolerated by the Emperor) it was easier to convert to the Reformation if a strong territory in the immediate neighbourhood had chosen the same path. The evidence thus points toward the importance of demandside factors rather than supply-side problems in the expansion of Protestantism.

To our knowledge, this is the first paper to investigate the motives of the adoption of certain denominations as state religions in a comparative fashion. Barro and McCleary (2005) discuss the determinants of the presence of state religion in the 2oth century, finding various factors that favor the adoption of state religions. Their research interest lies however in the mere presence or absence of a religion that enjoys official sanctioning, not in its actual denomination. Also, they explicitly refrain from "explain[ing] the motivations of Henry VIII in 1534 or Gustaf Vasa in $1527^{\prime \prime}$ (p. 1332), i.e. from considering the historical roots that led to the prevalence of certain denominations in given regions. More generally, in the economic literature the denominational characteristics of countries or their populations are mostly taken as given, often citing their persistence over time as a valid reason for their exogeneity with respect to other, present-day outcome variables. ${ }^{1}$

Among the historiographic literature comparative (or quantitative) enquiries of this kind are rare as well. More often, the focus is on single country/territory studies, pointing out the dynamics at work in those specific contexts. The essay closest to this project

\footnotetext{
${ }^{1}$ See, as an example, the study by Boppart et al. (2008).
} 
is a lecture by Walter Ziegler (2008). His discussion of factors promoting or pushing against the adoption of the Reformation yields a variety of predictions, but is not backed by a systematic quantitative analysis.

More broadly, analyzing the diffusion of a new religious denomination, such as Protestantism after its emergence in the 16th century, contributes to the varied literature about spatial patterns of adoption of social phenomena. Economists, political scientists and sociologists have explored these topics in the context of technology adoption (see, for example, Foster and Rosenzweig, 1995, or Conley and Udry, 2010) or, closer to the topic of this paper, of the spread of policies or of democratic institutions (Besley and Case, 1995; Markoff, 1996; Mukand and Rodrik, 2005; Dobbin et al., 2007).

The paper proceeds as follows. Section 2 gives a brief introduction to the historical context and the data used. The goal of section 3 is to provide an account of the factors empirically correlated with the adoption of the Reformation in a cross-section of territories of the Holy Roman Empire. Section 4 explains the crucial role of a territory's distance from Wittenberg through a model of spatial diffusion and of strategic externalities across neighbouring territories. Section 5 concludes.

\section{Setting and Data}

\subsection{Background history}

The object of this study are the territories of the Holy Roman Empire during the 16th century. ${ }^{2}$ Here, Martin Luther's protests against the Catholic Church were first voiced, and princes first broke with Rome to institute state churches based on the new creed.

\footnotetext{
${ }^{2} \mathrm{~A}$ concise introduction to the history of the Reformation in Germany with particular regard to the princely Reformation, i.e. the formal introduction of the Reformation at the hands of territorial lords, is given in Dixon (2000).
} 
In that period, the Holy Roman Empire (occupying areas corresponding to today's Germany, Austria, Belgium, Czech Republic, and other parts of Central Europe) was a loose federation of hundreds of states of different sizes and different institutional characteristics: monarchies, ecclesiastical territories, and Free Imperial cities. The Emperor was an elected sovereign, chosen by seven princes of the Empire (the Electors). Within this context, the gradual shift of essential components of sovereignty from the Emperor to the territories' princes was a process already in place at the beginning of the 16th century. In fact, the Reformation-by posing the question of who, if anyone, had the right to choose a territory's religious denomination-accelerated this process.

On October 31, 1517, Martin Luther, until then an unknown monk from Wittenberg in Saxony, voiced his objections against a series of practices of the Catholic church. As opposed to the case of other Church critics of the past (such as Jan Hus or Girolamo Savonarola), Luther's protest could develop and spread rapidly thanks to a series of fortunate coincidences: the power struggles between Emperor, Pope, and territorial lords, the recent invention of the printing press, the wars against the Ottoman Empire in Austria etc.

Whereas city burghers as well as large parts of the peasant population were soon attracted by the new creed, the formal adoption of Protestantism (on the territorial rulers' side) began only a decade after Luther's first protests. The legal and institutional context was unclear. The Emperor insisted on the fact that any decisions should be made only after the meeting of a general Church council; some princes argued instead that the situation required them to assume episcopal powers as "emergency bishops" (Notbischöfe) and proceeded with the foundation of state churches based on the Lutheran teachings.

The following decades were characterised by a progressively increasing assertiveness of the princes willing to introduce the Reformation, broken only by occasional inter- 
ventions of the Emperor. In 1543, he induced a major territory (the Duchy of JülichKleve-Berg) to desist from turning to Protestantism, and in 1547 he enjoyed a short-lived victory over the troops of the Protestant alliance of territories, the Schmalkaldic League. Finally, the formula "cuius regio, eius religio" (whose realm, his religion) was coined in the Peace of Augsburg (1555): it sanctioned the territorial lord's authority to introduce the Lutheran faith in their territories, if they wished, and gave them the right to impose this denominational choice on all their subjects. This formula effectively remained in place until the Peace of Westphalia (1648).

The religious choices of the 16th century were momentous and had long-lasting consequences. After the Thirty Years' War (1618-1648) had failed to deliver a clear winner, the denominational map of the Holy Roman Empire was effectively "frozen" to its state on January 1st, 1624, known as the normal date. Princes could still convert at will, but were not allowed to impose their choice on their subjects any more. The denominational split into Catholic and Protestant areas in Central Europe lasted over many centuries, also because of low spatial mobility and the virtual absence of intermarriage across religions. Still today, the relative preponderance of religious denominations in German regions reflects the choices of 16 th-century rulers.

\subsection{Data: Outcome variables and covariates}

The main dependent variable in the following analysis is the adoption of Protestantism on the side of territories or cities of the Holy Roman Empire. The cross-sectional analysis in section 3 considers as the outcome of interest whether a territory or city had adopted the Reformation by 1600 . This date, while arguably arbitrary, will in most cases reflect the first set of denominational choices operated in a territory. It will generally not capture subsequent changes due to military conquests in the Thirty Years' War or to dynastic 
successions. For the large majority of the territories, the situation in 1600 will be identical to the one of 1624, which was guaranteed by the Peace of Westphalia, and thus similar to the denominational split as of today.

The panel analysis of section 4 is based instead on the actual first date of formal adoption of Protestantism as the dependent variable. It is usually defined as the year in which a church ordinance (that is, a constitution) for the new, Protestant state church was drafted and introduced.

The selection of the 103 territories (inlcuding 37 Free Imperial cities) chosen for the analysis in this paper is based on the Bairoch et al. (1988) dataset of European cities: each one of these territories had at least one city which achieved a population of 5000 inhabitants or more at any time before 180o, and thus was included in the Bairoch et al. dataset.

The focus here is on the princely adoption of the Reformation, i.e. the introduction of the new religion through a territory's ruler as a legally binding act. An act of this kind is naturally easier to document than the informal diffusion of the new creed among the general population-which generally preceded the princes' choices. Moreover, since the choice of a territory's ruler was eventually imposed on its subjects in virtue of the principle "cuius regio, eius religio", the princely adoption can rightfully be seen as the relevant outcome to be analysed.

A broad array of covariates of interest, pertaining to 16th-century territories and cities, was collected from a variety of sources. Descriptions of these variables and the sources utilised are listed in Appendix A. It should be noted that some of the variables can only be defined at the level of cities instead of territories, motivating a separate cross-sectional analysis of the determinants of adoption at the city level in section 3.2. Territories in the 16th century were lacking the concept of a well-defined border in the 
modern sense. They were, rather, a compound of regions on which the prince enjoyed varying degrees of power, having to share many elements of sovereignty with other institutions (such as bishops or other princes) in some areas, but not in others. For this reason, and because of the lack of appropriate sources, it is virtually impossible to retrieve some variables of potential interest, such as the total population or the area of a territory in the 16th century.

Finally, an additional issue to be dealt with is the splitting and reunification of territories for dynastic reasons over the period analysed (from the inception of the Reformation until 160o). Since these changes could be endogenous to the Reformation process itself, the way in which they are dealt with in the econometric analysis could bias the results in either direction. The datasets used in the following sections consider as a unit of observation every territory that existed at any point during the 16th century and that contains a city included in the Bairoch et al. (1988) database. To take into account the necessary correlation between territories that were split off or reunited at some time, all standard errors are clustered at the highest level of aggregation reached by a compound of territories during the 16 th century. ${ }^{3}$

\section{Explaining the adoption of Protestantism}

\subsection{Territories}

The adoption of Protestantism by the territories of the Holy Roman Empire can be explained through a variety of historical characteristics of these regions. Of course, such regressions have to be interpreted with a grain of caution: whatever correlations emerge,

\footnotetext{
3 For example, two observations in the dataset are the territories of Hesse-Darmstadt and Hesse-Kassel, even though they were created only in 1567. Standard errors are clustered at the level of the old Landgraviate of Hesse ("territorial compound"), which comprised both territories before their separation.
} 
they should not necessarily be indicative of causal mechanisms at work. The assignment of specific socioeconomic characteristics to territories and cities is unlikely to be (as good as) random. Many of these characteristics are correlated with each other, so that they can be seen as proxies for other unobservables relating to a territory's history or culture. Still, detecting robust correlations in this dataset can give a hint as to which cultural, institutional, and economic settings were more likely to be inclined to the Reformation. This, in turn, can explain to which extent religious denomination can be considered exogenous when used to explain present-day or historical outcomes.

The regressions used here are simple linear probability models of the type:

$$
\text { Protestant }_{i, 1600}=x_{i}^{\prime} \beta+\varepsilon_{i}
$$

where the outcome variable, Protestant $t_{1,1600}$, equals one if territory $i$ is Protestant by 1600, and zero otherwise. The matrix $X$ contains a series of covariates, and $\beta$ is the corresponding vector of coefficients of interest.

\section{[Table 2 about here]}

The regressions in Table 2, columns 1-4, introduce a series of explanatory variables, grouped in broad categories. Column 1 considers geographic variables: the latitude and longitude of the territory's capital. Protestant territories tend to be more represented in the north of the Empire (higher degrees of latitude). The location of a territory on the east-west direction (longitude) does not appear to correlate strongly with religious choice: for example, the eastern parts of the Empire contained both Catholic Austria and Bohemia in the south, and Protestant Prussia and Pomerania in the north.

The second column considers an array of variables that are related to the economic power of the states: the number of cities in the Bairoch et al. (1988) database that are 
located within a territory, the total population living in those cities around 1500 (as a logarithm), the contribution of a territory to the Imperial war tax (Reichsmatrikel), and the presence of a university. Ziegler (2008) hypothesises that territories with universities had a more conservative attitude toward the Reformation: both because they had advanced further in the creation of a state bureaucracy trained in formal law (which thus had a vested interest in the status quo), and because they were naturally skeptical of new theological teaching coming from the most recent of all universities, Wittenberg. The contribution to the Imperial war tax (Reichsmatrikel), measuring the extent to which a territory contributed to the Empire's central budget, can be seen as a proxy for a territory's economic, military, or population size. ${ }^{4}$

In fact, of these economic variables only the contribution to the Reichsmatrikel has a significant effect on a territory's likelihood to embrace the Reformation. Larger and/or militarily more powerful territories were considerably less inclined to Protestantism; increasing the Reichsmatrikel contribution by one standard deviation (1.01 thousands of guilders) makes a territory $\mathbf{2 3 . 6}$ percentage points less likely to become Protestant. Note that this variable is unlikely to reflect differences in per-capita incomes. Rather, it will be a good proxy for a territory's total size, either in terms of population or in economic terms (the two will be equivalent if, as likely, variations in per capita income across territories were minor). This, in turn, was a determinant of its ability to contribute to military ventures. ${ }^{5}$

Column 3 introduces variables that can be broadly interpreted as reflecting the institutional setup of the territories. Here, the potential for reverse causality is particularly

\footnotetext{
4The figures contained in the Reichsmatrikel were established in 1521 and served as a key for allocating the Empire' expenditures (most notably, military expenses) for the following centuries.

${ }^{5}$ Another likely determinant of Reichsmatrikel contributions were prestige considerations: Electorsprinces with the right to elect the Emperor-were paying disproportionately more than other territories of otherwise comparable size.
} 
acute. For example, Sutter Fichtner (1989) argues that territories with a rule of succession based on primogeniture were more likely to remain Catholic; on the other hand, Protestantism-eliminating the option of sending second-born children to make career in the Church-also increased the attractiveness of partible inheritance. Another problem for "institutional" variables is that they are particularly hard to operationalise in a quantitative setting: Swanson (1967), for instance, hypothesised that "centralist" and "commensal" regimes were more likely to remain Catholic, "limited centralist," "balanced" and "heterarchic" regimes were more likely to become Protestant. Swanson's choice of examples is unfortunately very restricted; it is impossible to replicate his classification on all the territories of this dataset.

I thus limit myself to two institutional characteristics that are most easily observable: whether the territory was ecclesiastical (i.e., governed by a prince-bishop or another clergyman/woman), and whether the territory was a Free Imperial city (a city-state subject only to the suzerainty of the Emperor). The results in column 3 show that ecclesiastical territories were considerably less likely to become Protestant by 1600 . Conditional on ecclesiastical status, whether a state was a Free Imperial city had no effect on its likelihood to become Protestant.

The negative coefficient on the ecclesiastical status of a territory is, ex ante, not entirely obvious. In fact, one could expect some bishops to be enthusiastic adopters of the Protestant faith, as they could conceivably convert their territory into a normal state and make it a hereditary dynasty, especially if supported in this enterprise by a related dynasty. $^{6}$ Culturally, prince-bishops were not different from all other rulers: they often stemmed from the same noble families, as many bishoprics were effectively run as secundogenitures (the second-born son would be appointed bishop).

\footnotetext{
${ }^{6}$ This happened, for example, in the case of Lübeck, which was turned into a Protestant prince-bishopric in the hands of the Schleswig-Holstein-Gottorf dynasty.
} 
Finally, column 4 introduces a territory's capital's distance from Wittenberg as an explanatory variable. Becker and Wößmann (2009), who use it as an instrumental variable for the prevalence of Protestantism in 19th century Prussia, argue that this measure mattered because of the cost of spreading information. The estimated effect is significant at the $1 \%$ level, and important in magnitude: increasing a territory's distance to Wittenberg by one standard deviation $(133 \mathrm{~km})$ reduces its likelihood to embrace the Reformation by approximately 17 percentage points.

When all variables are pooled together in one regression (column 5), the picture is substantially unchanged: latitude, contribution to the Reichsmatrikel, ecclesiastical status, and distance to Wittenberg are the only economically and statistically significant predictors. In section 4, I will examine through which channel a territory's distance to Wittenberg influences its denominational choice.

Table 3 investigates the robustness of the previous findings. First, the same analysis of Table 2, column 5 , is replicated in selected subsamples. ${ }^{7}$ Column 1 excludes Free Imperial cities. As city-states run by a council representing the city's elites, those territories were acting in an entirely different institutional setting. As argued, for example, by Ozment (1975) and Moeller (1972), the teachings of the Reformation were particularly well-received by urban burghers; almost all Free Imperial cities eventually became Protestant (the only major exception being Cologne). Despite the geographic clustering of Free Imperial cities in the southwest of the Empire, the point estimate on "Distance to Wittenberg" is hardly affected by their exclusion from the dataset. Similarly, this central finding is unchanged when ecclesiastical territories are excluded (column 2).

[Table 3 about here]

\footnotetext{
7The point estimates for all other covariates except for "Distance to Wittenberg" are omitted, but generally close to those of Table 2, column 5. Results available upon request.
} 
Many historians writing biographies or country studies (especially in the 19th century) have stressed the role of some rulers' personal faith and convictions in introducing the Reformation in their territories. For example, the Elector of Saxony John Frederick I forcefully defended the introduction of the Reformation in his territory and wasaccording to all accounts-deeply convinced about its intrinsic truth and superiority. In many other cases it is difficult to disentangle personal conviction from personal convenience: Landgrave Philip of Hesse, another early and ardent supporter of the Reformation, chose to remarry after having turned to Protestantism. Variables relating to a prince's attitude are generally difficult to define quantitatively. However, one characteristic is easily observable: the ruler's age. In biographical studies, historians have at times pointed out how older rulers, having grown up in an age of religious certainty, were more hesitant in breaking away from the Roman Church, whereas younger rulers could more easily imagine a future with Protestant state churches.

Columns $3-5$ try to test this hypothesis. Still, it is unclear which precise age should matter in practice: the ruler's age in 1517 , when Luther first became known for his 95 Theses? Or in 1526, when the Diet of Speyer cautiously allowed princes to follow their conscience in religious matters, and when the first two major states (Saxony and Hesse) introduced the Reformation? Or in 1555, when the Peace of Augsburg finally sanctioned the right to introduce the new faith? For each one of the secular states (the age of bishops is probably less of a determinant of religious choice) the ruler's age at these three points in time is coded. The findings from Table 3, columns 3-5, however, are mixed: age in 1517 and in 1526 has no meaningful effect. A ruler's age in 1555 appears to have had a positive impact on Protestantism (older rulers were more likely to adopt the Reformation), but the point estimate is, while significant at the $5 \%$ level, small in magnitude. Increasing the ruler's age by one standard deviation (16.14 years) 
makes a territory only $16.14 \cdot 0.005 \cdot 100 \approx 8$ percentage points more likely to adopt the Reformation.

\subsection{Cities}

To reinforce and expand the findings about the determinants of the adoption of Protestantism, this section repeats the analysis using 249 cities of the Holy Roman Empire (drawn from the Bairoch et al., 1988 dataset) as the unit of observation. Divergences between a city's religious denomination and the territory's choice, while sometimes considerable in the early years of the Reformation (cities often hired Protestant preachers long before their territorial lords officially introduced the new faith), were rare around 1600. The "cuius regio, eius religio" provision of the Peace of Augsburg (1555) had either aligned the ruler's denominational choice with the one of its major cities, or given the ruler the tools (together with the ideological and institutional armamentarium of the Counterreformation) to enforce the return to Catholicism. ${ }^{8}$

The main reason for repeating the analysis at the city level is the ability to include a variety of covariates of interest that are hard to define at the territory level. Among these are characteristics of cities that may reflect its productive or economic structure: its location on a navigable river, its belonging to the Hanseatic league of cities (both signaling the likely preponderance of trading activity), or its age (signaling its growth trajectory: younger cities, mostly located in the eastern parts of the Empire, were more likely to grow fast than the older cities situated in the area of Roman colonization). Finally, a measure of the intensity of Church presence is introduced: the density of monasteries. ${ }^{9}$

\footnotetext{
${ }^{8}$ The major cases in which denominational choice around 1600 diverged at the city level from the territorial lord's choice are the Duchy of Jülich-Kleve-Berg, Austria ob der Enns, and the cities of Silesia (in all these cases, cities were Protestant, while the territorial lord remained Catholic).

${ }_{9}^{9}$ As explained in section 2.2, territories of the 16th century lacked the modern concept of an outside
} 
Moreover, a city-level regression naturally weighs the size of territories, assigning more observations to territories with many cities. To the extent that one might consider the religious choice of larger territories more indicative than the one of minor statelets, this is an attractive feature. Finally, smaller territories might be subject to greater measurement error, as information about the introduction of the Reformation is more difficult to find and verify than in those states that have been studied more extensively by the historical literature. At the same time, correlation of religious choice across cities within territories is taken into account by clustering standard errors at the level of territorial compounds.

\section{[Table 4 about here]}

The results in Table 4 largely reflect the findings of the territory-level analysis of Table 2. Many of the new covariates, such as the presence of a river, the age of the city, or the Hanseatic league status, have a significant effect when considered jointly with selected regressors, but their effect vanishes once all available explanatory variables are brought together (column 5). A city's distance to Wittenberg is still a primary determinant of religious denomination, as also evident from Figure 1.

[Figure 1 about here]

Perhaps the most interesting new covariate is the proxy for Church presence, monasteries per capita. Many authors (among others, Barro and McCleary, 2005) have hypothesised that the perspective of material gains was a motive for the introduction of Protestantism. Princes who became Lutheran or Calvinist could, in theory, expropriate

border delimiting the area of exclusive competence and sovereignty. For this reason, it is virtually impossible to count all monasteries lying on a given territory. The analysis of the effects of church presence (proxied by monasteries) is thus limited to the city-level analysis, where the determination of whether a monastery lay in a given city is comparatively uncontroversial. 
the Church's possessions: monasteries, agricultural lands, palaces in the cities. In addition they could secure considerable political powers by nominating the bishops and avoid paying taxes to Rome. Often, however, secularised Church property did not go directly into the princes' hands, but was the object of bargaining between princes and the estates - the local nobility was in fact wary of the prince appropriating too many powers. The revenues from these properties were needed to fund the newly-established state churches. Much effort was put into explaining that the Church's possessions were only "returned" to their originally intended, i.e. charitable use.

Even if the beneficiaries of the expropriation of Church lands were clearly defined, it is not clear whether a stronger presence of the Church on a territory would push a prince towards or against the Reformation: could a strong presence not be indicative of a stronger connection of the Church to the ruler and to civil society? Maybe it was precisely in these territories that the Church and the secular lords had found a particularly convenient way of coexistence and power-sharing. Therefore, more Church presence could make a prince less likely to embrace the Reformation. ${ }^{10}$

In fact, the regression results in Table 4, column 3, suggest that cities with a higher number of monasteries (normalised by the city's population) were less inclined toward the Reformation. However, the effect disappears once all other city-level covariates are included (column 5).

Separate attention is warranted to to the presence of Augustinian monasteries. Martin Luther was a monk of the Augustinian order and his brethren helped to spread his message: for example, the public disputation in Heidelberg in 1518, where Luther was

\footnotetext{
${ }^{10}$ Weber himself acknowledged these two sides of the coin by arguing that the Catholic church practiced a form of control over social and economic affairs that was severe in principle, but flexible in practice: "The rule of the Catholic Church, 'punishing the heretic, but indulgent to the sinner,' as it was in the past even more than today, is now tolerated by peoples of thoroughly modern economic character, and was borne by the richest and economically most advanced peoples on earth at about the turn of the fifteenth century." (Weber, 1930, pp. 34-35)
} 
given a chance to defend his arguments, was organised by the local Augustinian order. Many monasteries of the Augustinian order were closed in the years following the emergence of the Reformation, as most of the friars had embraced the Lutheran teachings. The regression results in columns 4 and 5 show no clear effect of the presence of Augustinian monasteries, though.

\section{Explaining the diffusion of Protestantism}

Why is a territory's distance from Wittenberg, the residence of the Electorate of Saxony and the seat of the university where Martin Luther taught, such a consistent and robust predictor of the adoption of Protestantism as official religion? Becker and Wößmann (2009), who use the distance to Wittenberg as an instrument for the prevalence of Protestantism in 19th century Prussian counties, put forward the following theory: the costs of traveling and of information diffusion were considerable in the 16th century, and thus it was easier for people close to Wittenberg to travel there and listen to Luther's preaching.

Attributing such importance to the costs of traveling and spreading information in the 16th century is probably exaggerated. While the expansion of the formal adoption of Protestantism took several decades, beginning in the 1520 s and effectively ending only shortly before the outbreak of the Thirty Years' War in 1618, the news about Luther's protest and his novel ideas spread rapidly all across the Holy Roman Empire within months, if not weeks. By June 1518 the pope had already summoned Luther to Rome, and by 1520 he had issued a bull (known as Exsurge Domine) condemning Luther's teachings. Consistent with this, Figure 2 shows the first date in which a Protestant preacher was recorded in any of the city's churches (as reported by the Deutsches Städtebuch; Keyser, 1939-1974) and maps it against the city's distance to Wittenberg. In fact, there is no apparent relationship between these two variables. 
[Figure 2 about here]

Luther was a prolific pamphleteer and understood the potential of the great innovation represented by Gutenberg's printing press (Edwards, 1994). Thanks also to this new medium, Luther's theses were rapidly known all over Germany. As soon as 1519-less than two years after the "95 Theses" were made public-Johannes Froben, a publisher from Basle (6o2 kilometers from Wittenberg), could write to Luther:

"We have sent 600 copies to Spain and France, and now they are also sold in Paris. [...] Calvus, the bookseller in Pavia, a very erudite and scientific man, wants to bring some of these booklets to Italy and disseminate them in all cities. [...] I have sold almost all of my copies, only ten are remaining, and I have never had such a fortunate turnover with any other book." (Schilling, 1988)

The absence of a relationship between a city's distance to Wittenberg and the ease of accessing Luther's works and ideas for the city's population is also displayed in Figure 3. It reports the number of editions of Luther's books published in cities of the Holy Roman Empire up to 1526, the year of the Diet of Speyer (which arguably gave the first, cautious green light to those territories that were willing to introduce reformed rites). The source of this information is the British Library's Short-title catalogue of books printed in the German-speaking countries (Johnson and Scholderer, 1965). Wittenberg features prominently with 191 editions, but is beaten by Augsburg (410 kilometers away from Wittenberg, as the crow flies) with 201 editions; apart from these two locations, other cities in the south of the Empire, such as Nuremberg, Strasbourg or Basel, were important centers of diffusion of Luther's ideas. Even cities in ecclesiastical territories, such as Erfurt or Bamberg, were printing several editions of Luther's books.

[Figure 3 about here] 
Distance to Wittenberg, however, could have mattered for a different reason. Introducing the Reformation was a risky venture for a territorial lord, especially in the years until 1555, for it was not clear whether the Imperial troops under Charles V would have intervened and imposed the return to the old faith at some point. Given this threat, a territory was more likely to embrace the Reformation if its neighbours had already done so. Territorial contiguity would have provided easier military defense in case of military conflict. The first state to commit credibly to stand by the Reformation's ideas would thus have produced a positive externality for its neighbours, making their choice to adopt the new faith less risky.

The Electorate of Saxony, the principality whose residence was Wittenberg, and in which Martin Luther happened to live and teach, was an early adopter of Luther's ideas: the first one to reform the Mass, the first one to establish a territorial church, the first one to perform a church visitation already in the 1520 s and 305 (Dixon, 2002, p. 122). No other major territory of the Empire, with the exception of the Landgraviate of Hesse, had committed so clearly to the new ideas by the end of the 1520 . The fact that Saxony was the first large state to adopt the Reformation could explain why the prevalence of Protestantism spread approximately concentrically around Wittenberg.

To verify to what extent a spatial expansion of the Reformation took place over time and how the conversion of neighbouring territories influenced princes to introduce the Reformation themselves it is useful to classify territories according to the year in which they formally introduced the Reformation. In many cases a precise date is difficult to pin down, as the introduction of the Reformation was a long process involving a multitude of steps: performing a church visitation to verify the state of each parish, hiring a known scholar of the Reformation to oversee the implementation of reform, writing a church ordinance (a constitution for the newly-formed territorial church), allowing the priests 
to marry and to dispense the Holy Communion sub utraque specie etc. Based on the historiographic literature (see Wolgast, n.d.), one can distinguish five different phases in the adoption of the Reformation, according to the legal and political setting that characterised those periods. With a considerable degree of certainty, it is possible to determine in which one of these five periods a territory adopted the Reformation:

- The first period (until 1532) includes all of the earliest adopters of the Reformation: the Electorate of Saxony (with Wittenberg as its residence) and the Landgraviate of Hesse as the two largest territories, as well as other statelets that pioneered the introduction of the new creed. In this period falls the Imperial Diet of Speyer (1526), in which it was stated that princes should behave in religious matters "as they may hope and trust to answer before God and his imperial Majesty," but also the Edict of Worms, in which an Imperial ban was imposed on Martin Luther. It was thus a period of considerable institutional uncertainty with regard to the legality of the new creed.

- The second period (1533-1538) begins with the Peace of Nuremberg and ends with the Peace of Frankfurt. With the Peace of Nuremberg Emperor Charles V, put under pressure by the looming danger of Ottoman troops (Iyigun, 2008), suspended the Edict of Worms and stopped all trials against Protestants running at the Imperial Chamber Court (Reichskammergericht). It thus represented a considerable step forward, making the legal environment safer for those territories willing to introduce the Reformation.

- The third period (1539-1548) follows the Peace of Frankfurt, in which Charles V reinforced the guarantees already given to the Protestants in the Peace of Nuremberg. In this phase, several large territories that had so far chosen a cautious path, 
such as Brandenburg, finally took firm steps towards introducing the Reformation. This period ends with the Schmalkaldic War, which-following the victory of the Imperial troops over the Protestant Schmalkaldic League-gave new strength to the supporters of the Catholic Church.

- The fourth period (1549-1555) starts with the Augsburg Interim. After the Imperial victory over the Schmalkaldic League, Protestants were supposed to adopt the Interim (a compromise creed) as a first step towards eventual reunification of the churches. However, Charles' position in the Empire weakened considerably over the following years. With the Peace of Passau first (1552) and the Peace of Augsburg later (1555) he had to warrant again the right to introduce and practice the Protestant faith.

- The fifth period (1556-1600) is characterised by the formula coined in the Peace of Augsburg: "cuius regio, eius religio" (whose realm, his religion). It effectively ended any attempt on the Imperial and Papal side to interdict the introduction of the Reformation and gave princes the right to impose their denominational choice on their subjects.

Based on this division in five periods, Table 5 shows that a territory's capital distance to Wittenberg does not simply correlate with the eventual adoption of Protestantism, but also with the timing of adoption: the further away, the later the introduction of the Reformation. The highest average distance is recorded for those territories that never became Protestant. This relationship breaks down in the last period, after the Peace of Augsburg (1555): in those last decades of the 16th century, the princes' right to introduce the Reformation was clearly sanctioned by the formula "cuius regio, eius religio." As opposed to previous peace agreements between the Emperor and the Protestant princes, 
this achievement was never endangered; the Peace of Augsburg meant the definitive renunciation of the Emperor's attempts to impose religious unity. Thus, after 1555 it was no longer necessary to rely on powerful neighbours to be safe when introducing the Reformation.

\section{[Table 5 about here]}

The role of neighbourhood spillovers in the territories' decisions to adopt the Reformation can be formally examined in an econometric setup. Based on the division of the 16th century in five different phases of expansion of Protestantism, the following predictions can be tested in order to distinguish the role of strategic neighbourhood spillovers from a theory where distance to Wittenberg matters because of information diffusion costs.

First, if strategic spillovers are relevant, a neighbour's choice to commit to the introduction of the Reformation should make a territory more likely to introduce the Reformation as well (since expected costs fall). Instead, if distance to Wittenberg matters because of information costs, the Reformation spreads across space and time independently of whether neighbouring territories actually adopt it or not. Second, smaller territories should profit from these neighbourhood effects more than large territories (which might have enough military power to defend themselves against Imperial reprisals). Third, the effect of neighbours' denominational choice should be largest in the early phases, when the legal/institutional setting was still hazy with regard to the legality of the adoption of Protestantism, and lowest toward the end of the 16th century, when the Peace of Augsburg guaranteed every prince the right to change his territory's religious denomination.

A measure of each territory's neighbours' leanings toward Protestantism is created as a weighted sum of indicators (whether neighbour $j$ has formally adopted the Reformation by the end of phase $t$ ). The weights are given by the inverse of the great circle 
distance between the territories' capitals. This weighted sum is then normalised using the sum of all inverse distances separating the capital of $i$ from all other capitals. As a result of this normalization, the measure assumes a value bounded between zero and one:

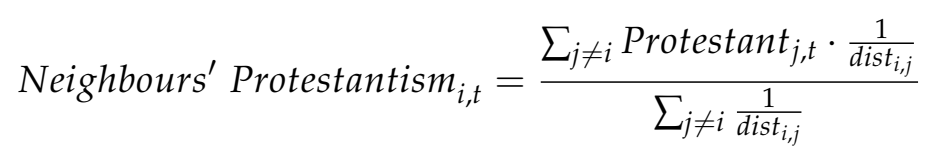

To test for the presence of strategic spillovers, a spatial/temporal lag model is assumed: a territory's decision to introduce the Reformation is assumed to be a function of its neighbours' decisions in the preceding time period:

$$
\text { Protestant }_{i, t}=\beta_{0}+\beta_{1} \cdot \text { Neighbours }^{\prime} \text { Protestantism }_{i, t-1}+\varepsilon_{i, t}
$$

Note that since the spatial lag in the dependent variable is not contemporaneous, but refers to the preceding period, this model can be estimated simply by ordinary least squares (instead of maximum likelihood). This regression setup can be augmented by using territory and time fixed effects, $\zeta_{i}$ and $\xi_{t}$ :

$$
\text { Protestant }_{i, t}=\zeta_{i}+\zeta_{t}+\beta_{1} \cdot \text { Neighbours' }^{\prime} \text { Protestantism }_{i, t-1}+\varepsilon_{i, t}
$$

In such a setup all territory-specific, time-invariant characteristics (such as the capital's distance to Wittenberg) are absorbed by the territory fixed effects.

The results of estimating such spatial/temporal lag models are presented in Table $6 .{ }^{11}$ Column 1, corresponding to the setup of equation (3), shows that the (weighted) number of neighbours inclined to the Protestant Reformation has a positive and significant effect

\footnotetext{
${ }^{11}$ The panel dataset does not include Free Imperial cities, as they arguably decided over their religious denomination in a different institutional setting: there, the religious choice was not taken by a ruler and eventually enforced by virtue of the provisions of the Peace of Augsburg, but taken by a city council or a similar organ representing the city's elites.
} 
on a territory's choice to introduce the Reformation in the following period. The economic magnitude of the coefficients is considerable: increasing the weighted fraction of Protestant neighbours by 0.2 (approximately one standard deviation) makes a territory $0.2 \cdot 0.861 \cdot 100 \approx 17$ percentage points more likely to adopt the Reformation one period later (the magnitude of coefficients can be readily interpreted as the setup corresponds to a linear probability model).

\section{[Table 6 about here]}

The results of column 1 are drawn from a pooled OLS setup. Column 2, introducing territory fixed effects, relies on the within-territory variation only to estimate the effect of neighbours' denominational choice. In this context, time invariant characteristics of a territory, such as its distance from Wittenberg, are taken into account by the fixed effect. Magnitude and significance of the point estimate of interest are unaffected.

The precision of the estimated effect of (lagged) neighbours' Protestantism decreases notably with the introduction of time fixed effects (column 3). This is not surprising, as this variable is clearly correlated with a time trend. Since selection into Protestantism was effectively an absorbing state, the variable "lagged neighbours' Protestantism" continuously increases over time.

Large territories, being able to rely on enough own military clout, should profit less from the positive externality represented by neighbours' conversion to Protestantism: this prediction is tested in column 4. Here, the value of neighbours' lagged Protestantism is interacted with a territory's own contribution to the Imperial war tax, the Reichsmatrikel. Larger territories contributed more troops, horses, and financial means to the Imperial military budget. As expected, the coefficient on the interaction term has a negative value (significant at the $5 \%$ level), indicating that larger territories were less influenced by their neighbours' choices. 
The last prediction from a theory of strategic neighbourhood interactions regards the timing of adoption. Column 5 shows how the effect of neighbours' Protestantism, in a two-way fixed effects model as in equation (4), can be analyzed separately for each one of the phases of expansion of the Reformation that constitute the time structure of the panel dataset. To this purpose, the variable corresponding to neighbours' lagged Protestantism is interacted with a series of time dummies, each one of which corresponds to one of the phases (with the exception of the first phase):

$$
\text { Protestant }_{i, t}=\zeta_{i}+\xi_{t}+\sum_{\tau \in \mathcal{T}} \beta_{\tau} \cdot \text { Neighbours' }^{\prime} \text { Protestantism }_{i, t-1} \cdot I_{\tau}+\varepsilon_{i, t}
$$

In this equation, $I_{\tau}$ is a dummy for time period $\tau$, and $\mathcal{T}$ is the set of all time periods in the dataset bar the first one. The coefficients of interest are the sequence of $\beta_{\tau}$, representing the effect of lagged neighbours' choice of denomination, split up by time periods.

Consistent with the view that the institutional surrounding made the adoption of Protestantism a safer choice the more time progressed (with the only exception, maybe, of the Emperor's short-lived period of strength after 1548), the magnitude of estimated effects declines considerably over time. In the second period (1533-1538), territories whose neighbours were among the pioneers in introducing the Reformation (i.e., those who introduced it before 1532) were significantly more likely to adopt the Reformation themselves. In fact, the magnitude of the point estimate (1.958) suggests an effect more than twice as large than the overall effect of lagged neighbours' Protestantism as estimated in columns $1-3$. In the subsequent phases, the strategic advantage of having like-minded neighbours fades; the point estimates are smaller in magnitude and do not reach conventional levels of significance.

This finding is reinforced by the analysis in column 6. As previously pointed out 
the direct effects of a territory's distance to Wittenberg are subsumed in the territory fixed effects. However, to the extent that distance to Wittenberg and neighbours' denominational choices are correlated, the regression in column 5 might just be picking up a time-varying effect of distance to Wittenberg: for example, if the diffusion of information about the Reformation (and not strategic interactions) was the relevant mechanism at work, distance to Wittenberg could matter less and less over time because at some point the news about Martin Luther would have reached everyone. As a test of these concurrent explanations, column 6 features both the interactions of neighbours' lagged Protestantism with time period dummies, and the interactions of a territory's distance to Wittenberg with time dummies. In fact, the effect of distance to Wittenberg hardly changes over time, whereas the role of lagged neighbours' choices is still strong and significant at the beginning of the expansion, and weakest in the last period (when the legality of introducing the Reformation had been sanctioned by the Peace of Augsburg). ${ }^{12}$

\section{Conclusion}

What determines whether a state embarks in a momentous institutional change, such as the adoption of a new state religion? The evidence from 16th-century Germany is important in two respects. First, religious choices of the territorial rulers of the time had particularly long-lasting consequences, as the denominational map of Germany today is highly correlated with that of 1600 . To the extent that religious denominations have

\footnotetext{
${ }^{12}$ An alternative theory would point toward the informational content of neighbours implementing the Reformation: rulers of a territory would learn from their neighbours how to introduce the new faith to their territories, taking into account local conditions (akin to the ideas exposed in the literature on the diffusion of technologies or policies; see section 1). While this theory would be difficult to tell apart from the military-strategic considerations put forward in this section, it is unlikely to be a fitting description of adoption dynamics. Sovereigns of the 16th century had frequent exchange through correspondence or through meetings at the Imperial Diets, and scholars advising them on how to implement the Reformationsuch as Melanchthon, Bugenhagen, Bucer etc.--traveled from court to court all across the Empire.
} 
a direct impact on socioeconomic outcomes, understanding their historical origins is of particular importance. Second, it can be argued that the dynamics of institutional adoption in early modern Europe harbor insights, e.g. about the role of imitation, for the spread of policies across states today.

Only few territory characteristics are found to be consistent predictors of the adoption of Protestantism. Among these, a territory's distance to Wittenberg, the city where Martin Luther lived and taught, is preeminent. This finding, it is argued, is unlikely to depend on the cost of spreading information about the Reformation. The key factor at work was instead the early and committed adoption of Protestantism at the hands of the Elector of Saxony, the territory surrounding Wittenberg.

During the first decades after the emergence of Luther's protests, his teachings spread rapidly and were willingly accepted by large strata of the population; territorial lords, however, were more prudent in joining Protestantism. The legal foundations of such a move were unclear. There was no precedent for the change of official denomination at the hands of territorial lords, and the Emperor, suzerain of all princes of the Holy Roman Empire, argued in favor of the primacy of Church councils in religious matters.

In this context, the move of a major prince of the Empire, such as Saxony's commitment to the new creed, can have a positive externality on its neighbours' decisions. It effectively reduced the risk of introducing the new faith by signalling that other territories were embarking on the same path, and were potentially willing to defend their decision with their military weight. Consistent with this theory, the panel data analysis in this paper shows that neighbours' religious choices have a strong impact on a territory's own decision; that the effect of neighbours' choices is more important for smaller territories rather than for larger (and arguably militarily more powerful) ones; and that the effect varies through time depending on the legal and institutional context. 


\section{References}

Arruñada, Benito, "Protestants and Catholics: Similar Work Ethic, Different Social Ethic," Economic Journal, 2010, 120 (547), 890-918.

Bai, Ying and James Kai-sing Kung, "Diffusing Useful Knowledge while Spreading God's Message: Protestantism and Economic Prosperity in China, 1840-1920," February 2011. Unpublished, Hong Kong University of Science and Technology.

Bairoch, Paul, Jean Batou, and Pierre Chèvre, La population des villes européennes, 8001850: Banque de données et analyse sommaire des résultats, Geneva: Droz, 1988.

Barro, Robert J. and Rachel M. McCleary, "Which Countries Have State Religions?," Quarterly Journal of Economics, November 2005, 120 (4), 1331-1370.

Becker, Sascha O. and Ludger Wößmann, "Was Weber Wrong? A Human Capital Theory of Protestant Economic History," Quarterly Journal of Economics, May 2009, 124 (2), 531-596.

Besley, Timothy and Anne Case, "Incumbent Behavior: Vote-Seeking, Tax-Setting, and Yardstick Competition," American Economic Review, 1995, 85 (1), 25-45.

Boppart, Timo, Josef Falkinger, Volker Grossmann, Ulrich Woitek, and Gabriela Wüthrich, "Qualifying Religion: The Role of Plural Identities for Educational Production," IZA Discussion Papers 3408, Institute for the Study of Labor (IZA) March 2008.

Cantoni, Davide, "The Economic Effects of the Protestant Reformation: Testing the Weber Hypothesis in the German Lands," December 2010. Universitat Pompeu Fabra Working Paper Series, 1260.

Conley, Timothy G. and Christopher R. Udry, "Learning about a New Technology: Pineapple in Ghana," American Economic Review, 2010, 100 (1), 35-69.

Delacroix, Jacques and François Nielsen, "The Beloved Myth: Protestantism and the Rise of Industrial Capitalism in Nineteenth-Century Europe," Social Forces, December 2001, 80 (2), 509-553.

Dixon, C. Scott, "The Princely Reformation," in Andrew Pettegree, ed., The Reformation World, London, New York: Routledge, 2000, chapter 9.

_ , The Reformation in Germany, Oxford: Oxford University Press, 2002.

Dobbin, Frank, Beth Simmons, and Geoffrey Garrett, "The Global Diffusion of Public Policies: Social Construction, Coercion, Competition, or Learning?," Annual Review of Sociology, 2007, 33, 449-472. 
Edwards, Mark U., Printing, Propaganda, and Martin Luther, Berkeley, Calif.: Berkeley University Press, 1994.

Foster, Andrew D. and Mark R. Rosenzweig, "Learning by Doing and Learning from Others: Human Capital and Technical Change in Agriculture," Journal of Political Economy, 1995, 103 (6), 1176-1209.

Guiso, Luigi, Paola Sapienza, and Luigi Zingales, "People's opium? Religion and economic attitudes," Journal of Monetary Economics, 2003, 50, 225-282.

Hammel-Kiesow, Rolf, Die Hanse, München: C.H. Beck, 2000.

Historische Kommission bei der (Königl.) Bayerischen Akademie der Wissenschaften, ed., Allgemeine Deutsche Biographie, Leipzig: Duncker \& Humblot, 56 vols., 1875-1912.

_, ed., Neue Deutsche Biographie, Berlin: Duncker \& Humblot, 24 vols., 1957-2010.

Iyigun, Murat, "Luther and Suleyman," Quarterly Journal of Economics, November 2008, 123 (4), 1465-1494.

Johnson, Alfred F. and Victor Scholderer, Short-title catalogue of books printed in the German-speaking countries and German books printed in other countries from 1455 to 1600 now in the British Museum, London: Trustees of the British Museum, 1965.

Jürgensmeier, Friedhelm and Regina E. Schwerdtfeger, eds, Orden und Klöster im Zeitalter von Reformation und katholischer Reform, 1500-1700, Münster: Aschendorff, 3 vols., 2005-2008.

Keyser, Erich, Deutsches Städtebuch, Stuttgart: Kohlhammer, 5 vols., 1939-1974.

Krause, Gerhard and Gerhard Müller, eds, Theologische Realenzyklopädie, Berlin, New York: de Gruyter, 36 vols., 1977-2004.

Kunz, Andreas, ed., Statistik der Binnenschiffahrt in Deutschland 1835-1989, Vol. 1, St. Katharinen: Scripta Mercaturae, 1999.

Markoff, John, Waves of Democracy: Social Movements and Political Change, Thousand Oaks, Calif.: Pine Forge Press, 1996.

Moeller, Bernd, Imperial Cities and the Reformation, Philadelphia: Fortress Press, 1972.

Mukand, Sharun W. and Dani Rodrik, "In Search of the Holy Grail: Policy Convergence, Experimentation, and Economic Performance," American Economic Review, 2005, 95 (1), 374-383.

Ozment, Steven E., The Reformation in the Cities: The Appeal of Protestantism in Sixteenth Century Germany and Switzerland, New Haven: Yale University Press, 1975. 
Rashdall, Hastings, The Universities of Europe in the Middle Ages, Oxford: Clarendon Press, 1895.

Schilling, Heinz, Aufbruch und Krise: Deutschland 1517-1648, Berlin: Siedler, 1988.

Schindling, Anton and Walter Ziegler, eds, Territorien des Reichs im Zeitalter der Reformation und Konfessionalisierung, Münster: Aschendorff, 7 vols., 1989-1997.

Sutter Fichtner, Paula, Protestantism and Primogeniture in Early Modern Germany, New Haven: Yale University Press, 1989.

Swanson, Guy E., Religion and Regime: A Sociological Account of the Reformation, Ann Arbor: University of Michigan Press, 1967.

Weber, Max, "Die protestantische Ethik und der 'Geist' des Kapitalismus," Archiv für Sozialwissenschaften und Sozialpolitik, 1904/05, 20-21, 17-84; 1-110. English Translation: The Protestant Ethic and the Spirit of Capitalism, London: Allen \& Unwin, 1930.

Wolgast, Eike, "Einführung der Reformation und Schicksal des Kirchengutes," n.d. Manuscript.

Woodberry, Robert D., "Religious Roots of Economic and Political Institutions," in Rachel M. McCleary, ed., Oxford Handbook of the Economics of Religion, Oxford: Oxford University Press, 2010.

Zeumer, Karl, ed., Quellensammlung zur Geschichte der deutschen Reichsverfassung in Mittelalter und Neuzeit, Vol. 2, Tübingen: J.G.B. Mohr (Paul Siebeck), 2nd ed. 1913.

Ziegler, Walter, "Territorium und Reformation. Überlegungen zur Entscheidung der deutschen Länder für oder gegen Luther," in Walter Ziegler, ed., Die Entscheidung der deutschen Länder für oder gegen Luther, Münster: Aschendorff, 2008, chapter I.3. 


\section{A Data Sources}

\begin{tabular}{|c|c|}
\hline Variable & Description and Source \\
\hline Age of the city & $\begin{array}{l}\text { Age of the city (based on the year of official incorpo- } \\
\text { ration) in 1517, measured in centuries. Source: Keyser } \\
(1939-1974) \text {. }\end{array}$ \\
\hline Age of the ruler & $\begin{array}{l}\text { Age of a territory's ruler at the given date. In presence } \\
\text { of a legal warden, the warden's age is used; where } \\
\text { multiple rulers (usually brothers) ruled together, the } \\
\text { average age is used. Sources: Historische Kommis- } \\
\text { sion bei der (Königl.) Bayerischen Akademie der Wis- } \\
\text { senschaften, ed (1875-1912, 1957-2010); Schindling } \\
\text { and Ziegler, eds (1989-1997), and Wikipedia. }\end{array}$ \\
\hline Augustinian monasteries & $\begin{array}{l}\text { Number of Augustinian monasteries in existence in } \\
1517 \text { within 1okm from the city center (great circle dis- } \\
\text { tance). Source: Jürgensmeier and Schwerdtfeger, eds } \\
\left(2005^{-2008) .}\right.\end{array}$ \\
\hline Distance to Wittenberg & $\begin{array}{l}\text { Great circle distance of a city to Wittenberg, measured } \\
\text { in } 100 \text { 's of } \mathrm{km} \text {. Source: own calculations. }\end{array}$ \\
\hline Ecclesiastical & $\begin{array}{l}\text { Binary, } 1 \text { if city belongs to an ecclesiastical territory } \\
\text { Source: Keyser (1939-1974). }\end{array}$ \\
\hline Free Imperial City & $\begin{array}{l}\text { Binary, } 1 \text { if city has Free Imperial status (subject only } \\
\text { to the immediate suzerainty of the Emperor) in } 1517 \\
\text { Sources: Keyser (1939-1974) and the Reichsmatrike } \\
\text { (Zeumer, ed, 1913). }\end{array}$ \\
\hline Hanseatic & $\begin{array}{l}\text { Binary, } 1 \text { if city belonged to the Hanseatic league in } \\
\text { the } 15^{\text {th }} \text { century. Source: Hammel-Kiesow (2000). }\end{array}$ \\
\hline Lagged neighbours' Protestantism & See variable construction description in section 4 \\
\hline Latitude & Latitude of the city in degrees (north). Source: passim \\
\hline Longitude & Longitude of the city in degrees (east). Source: passim \\
\hline Monasteries (p.c.) & $\begin{array}{l}\text { Number of monasteries (not belonging to mendicant } \\
\text { orders) in existence in } 1517 \text { within 1okm from the city } \\
\text { center (great circle distance), divided by total popu- } \\
\text { lation in } 1500 \text { (in 1000's). If there is no population } \\
\text { figure for a city in } 1500 \text {, city size is assumed to equal } \\
\text { 1000. Source: Jürgensmeier and Schwerdtfeger, eds } \\
(2005-2008) \text {. }\end{array}$ \\
\hline
\end{tabular}

Continued on next page 


\begin{tabular}{|c|c|}
\hline Variable & Description and Source \\
\hline Number of cities & $\begin{array}{l}\text { Number of cities (with and without reported popu- } \\
\text { lation sizes) in the Bairoch et al. (1988) database be- } \\
\text { longing to a given territory. Inclusion criterion is hav- } \\
\text { ing reached } 5000 \text { inhabitants at any time before } 1800 \text {. } \\
\text { Source: Bairoch et al. (1988). }\end{array}$ \\
\hline Population in 1500 & $\begin{array}{l}\text { Population of a city in thousands. Missing values are } \\
\text { imputed assuming a population of } 1000 \text { (lower thresh- } \\
\text { old in the Bairoch et al. (1988) database). Source: } \\
\text { Bairoch et al. (1988) }\end{array}$ \\
\hline Protestant by 1600 & $\begin{array}{l}\text { Binary, } 1 \text { if Protestantism is the only or dominant } \\
\text { religious denomination in a city/territory in 1600. } \\
\text { Sources: Krause and Müller, eds (1977-2004); Schin- } \\
\text { dling and Ziegler, eds (1989-1997) and Keyser (1939- } \\
\text { 1974). }\end{array}$ \\
\hline Protestant by the end of period $t$ & $\begin{array}{l}\text { Binary, } 1 \text { if Protestantism has been officially intro- } \\
\text { duced as official religion by the end of period } t \text { or } \\
\text { before. Sources: Historische Kommission bei der } \\
\text { (Königl.) Bayerischen Akademie der Wissenschaften, } \\
\text { ed (1875-1912, 1957-2010); Krause and Müller, eds } \\
\text { (1977-2004); Schindling and Ziegler, eds (1989-1997) } \\
\text { and Wolgast (n.d.). }\end{array}$ \\
\hline Reichsmatrikel contribution & $\begin{array}{l}\text { Total contribution of a territory to the expenditures } \\
\text { of the Empire (in guilders). I used the conventional } \\
\text { correspondences of } 1 \text { footed soldier }=4 \text { guilders and } \\
1 \text { cavalry soldier }=12 \text { guilders to translate the single } \\
\text { values into a total contribution. Source: Zeumer, ed } \\
\text { (1913). }\end{array}$ \\
\hline River & $\begin{array}{l}\text { Location on a navigable river. Source: Kunz, ed } \\
\text { (1999), map of navigable rivers as of } 1800 \text {. }\end{array}$ \\
\hline University & $\begin{array}{l}\text { Binary, } 1 \text { if the city/territory is the seat of an active } \\
\text { university in } 1517 \text {. Source: Rashdall (1895). }\end{array}$ \\
\hline Urban population in 1500 & $\begin{array}{l}\text { Total population of all cities present in the Bairoch et } \\
\text { al. (1988) database belonging to a given territory. }\end{array}$ \\
\hline
\end{tabular}




\section{B Figures and Tables}

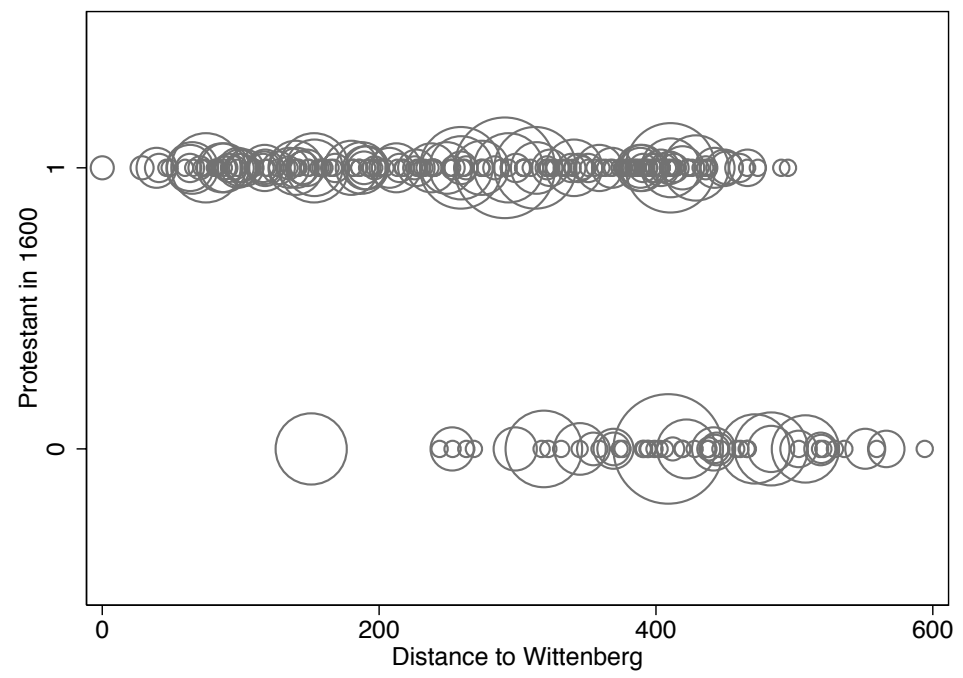

Figure 1: Protestantism in 1600 and distance to Wittenberg for cities in the dataset (circle size proportional to city population in 1500) 


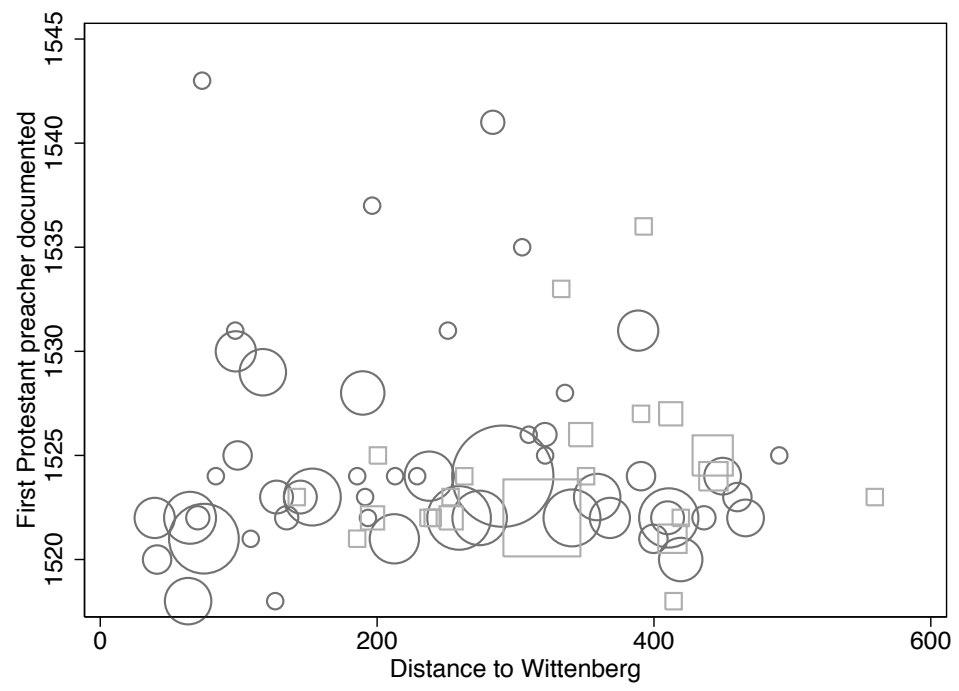

Figure 2: First year of Protestant preaching and distance to Wittenberg (circles represent cities that would eventually become Protestant, squares cities that would remain Catholic. Symbol size proportional to city population in 1500)

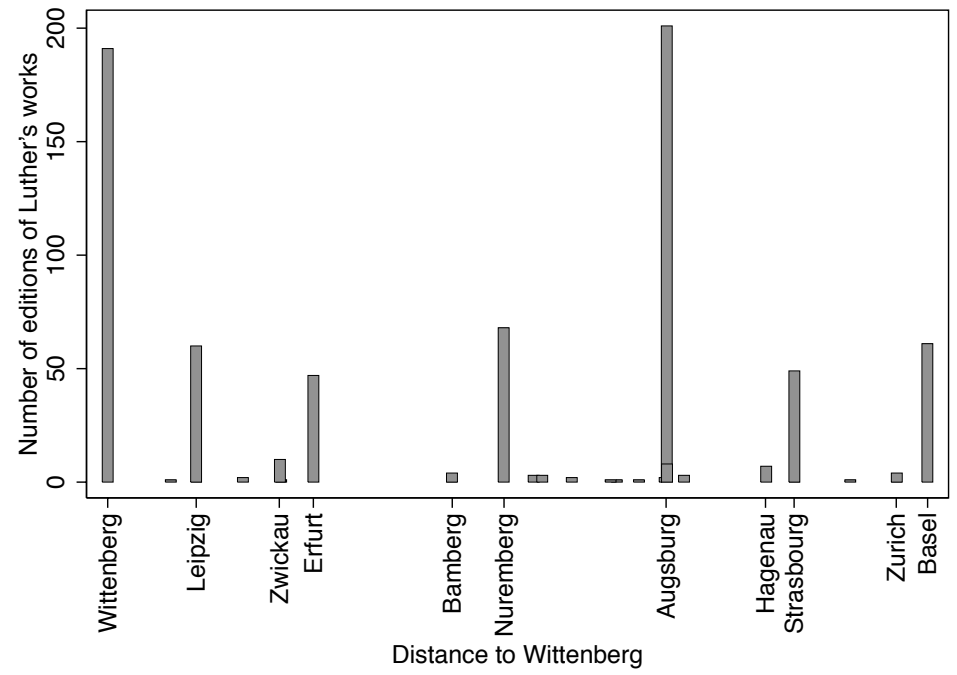

Figure 3: Number of editions of Luther's works published up to 1526 and distance to Wittenberg (selected cities labeled) 
Table 1: Summary statistics

\begin{tabular}{|c|c|c|c|c|c|c|c|}
\hline \multirow[t]{2}{*}{ Variable } & \multirow[t]{2}{*}{ Mean } & \multirow[t]{2}{*}{ Std. Dev. } & \multirow[t]{2}{*}{ Min. } & \multirow[t]{2}{*}{ Max. } & \multicolumn{2}{|c|}{ Mean } & \multirow[t]{2}{*}{ t-stat } \\
\hline & & & & & Catholic & Protestant & \\
\hline \multicolumn{8}{|l|}{ Panel A: Territory-level data } \\
\hline Protestant by 1600 & 0.71 & 0.46 & $\mathrm{O}$ & 1 & $\mathrm{O}$ & 1 & . \\
\hline Latitude & 50.59 & 1.78 & 47.67 & 55.68 & $49 \cdot 73$ & 50.93 & $-3 \cdot 57$ \\
\hline Longitude & 9.99 & 2.10 & 6.08 & 16.33 & $9 \cdot 45$ & 10.20 & -1.42 \\
\hline Number of cities & 1.18 & 1.68 & o & 11 & 1.37 & 1.11 & 0.67 \\
\hline Urban population in 1500 (log) & 1.45 & 1.22 & $\mathrm{O}$ & 4.13 & 1.58 & 1.39 & 0.68 \\
\hline Reichsmatrikel contribution & 0.97 & 1.01 & 0.02 & 7.20 & 1.58 & 0.73 & 2.97 \\
\hline University & 0.12 & 0.32 & $\mathrm{O}$ & 1 & 0.20 & 0.08 & 1.47 \\
\hline Ecclesiastical & 0.18 & 0.39 & $\mathrm{O}$ & 1 & 0.43 & 0.08 & 3.62 \\
\hline Free Imperial City & 0.36 & 0.48 & $\mathrm{O}$ & 1 & 0.23 & 0.41 & -1.77 \\
\hline Distance to Wittenberg & 3.12 & 1.33 & $\mathrm{O}$ & $5 \cdot 78$ & 3.93 & 2.79 & $4 \cdot 91$ \\
\hline Age of the ruler in 1517 & 41.99 & 13.23 & 18 & 75 & 44.80 & 41.25 & 0.60 \\
\hline Age of the ruler in 1526 & 43.05 & 12.92 & 22 & 66 & $39 \cdot 30$ & 44.04 & -1.03 \\
\hline Age of the ruler in 1555 & 42.67 & 16.14 & 17 & 75 & 38.10 & 43.87 & -1.16 \\
\hline \multicolumn{8}{|l|}{ Panel B: City-level data } \\
\hline Protestant & 0.77 & 0.42 & $\mathrm{O}$ & 1 & $\mathrm{O}$ & 1 & . \\
\hline Latitude & 50.82 & 1.70 & 46.63 & $54 \cdot 47$ & $49 \cdot 47$ & 51.22 & $-7 \cdot 44$ \\
\hline Longitude & 10.73 & 2.81 & 6.08 & 17.93 & 9.87 & 10.99 & -2.56 \\
\hline River & 0.36 & 0.48 & $\mathrm{O}$ & 1.00 & 0.40 & 0.35 & 0.74 \\
\hline Population in $1500(\log )$ & 0.77 & 1.00 & $\mathrm{O}$ & 3.81 & 0.82 & 0.75 & 0.39 \\
\hline Age of the City & 5.68 & $3 \cdot 37$ & 0.20 & $15 \cdot 75$ & $7 \cdot 72$ & 5.08 & $4 \cdot 30$ \\
\hline Ecclesiastical & 0.14 & 0.34 & $\mathrm{O}$ & 1 & 0.42 & 0.05 & $5 \cdot 43$ \\
\hline Monasteries (p.c.) & 1.26 & 1.73 & $\mathrm{O}$ & 15 & 1.99 & 1.04 & $3 \cdot 30$ \\
\hline University & 0.05 & 0.22 & $\mathrm{O}$ & 1 & 0.12 & 0.03 & 2.01 \\
\hline Free Imperial City & 0.15 & 0.36 & $\mathrm{O}$ & 1 & 0.12 & 0.16 & -0.65 \\
\hline Hanseatic & 0.10 & 0.31 & $\mathrm{O}$ & 1 & 0.05 & 0.12 & -1.77 \\
\hline Distance to Wittenberg & 2.93 & 1.37 & $\mathrm{O}$ & $5 \cdot 94$ & 4.13 & 2.57 & 10.22 \\
\hline Augustinian monasteries & 0.19 & 0.40 & $\mathrm{O}$ & 2 & 0.26 & 0.17 & 1.39 \\
\hline \multicolumn{8}{|l|}{ Panel C: Panel data } \\
\hline Lagged Neighbours' Protestantism & 0.30 & 0.19 & 0.00 & 0.68 & 0.28 & 0.30 & -1.09 \\
\hline Lagged Neighbours' Prot. (1533-1538) & 0.21 & 0.05 & 0.13 & 0.35 & 0.20 & 0.21 & -1.07 \\
\hline Lagged Neighbours' Prot. (1539-1548) & 0.30 & 0.07 & 0.19 & 0.51 & 0.27 & 0.32 & -2.63 \\
\hline Lagged Neighbours' Prot. (1549-1555) & 0.46 & 0.08 & 0.33 & 0.62 & 0.44 & 0.47 & -1.76 \\
\hline Lagged Neighbours' Prot. (1555-1600) & 0.51 & 0.08 & 0.37 & 0.68 & 0.49 & 0.52 & -1.55 \\
\hline
\end{tabular}

Cf. also variables definitions in Appendix A. Reichsmatrikel contribution in thousands of guilders. Distance to Wittenberg in hundreds of kilometers (great circle distance). Monasteries (p.c.) are expressed per thousand inhabitants. T-statistics based on t-tests of differences in means, with unequal variances. 
Table 2: Adoption of Protestantism-Territory-level regressions

\begin{tabular}{|c|c|c|c|c|c|}
\hline \multirow[t]{3}{*}{ Dependent variable } & \multicolumn{5}{|c|}{ Territory Protestant by 1600} \\
\hline & Geography & Economy & Institutions & Information & All \\
\hline & (1) & (2) & (3) & (4) & (5) \\
\hline Latitude & $\begin{array}{c}0.076^{* * *} \\
{[0.023]}\end{array}$ & & & & $\begin{array}{l}0.048^{* *} \\
{[0.021]}\end{array}$ \\
\hline Longitude & $\begin{array}{c}0.022 \\
{[0.027]}\end{array}$ & & & & $\begin{array}{c}0.030 \\
{[0.025]}\end{array}$ \\
\hline Number of cities & & $\begin{array}{c}0.040 \\
{[0.033]}\end{array}$ & & & $\begin{array}{c}-0.021 \\
{[0.033]}\end{array}$ \\
\hline Urban population in $1500(\log )$ & & $\begin{array}{c}0.041 \\
{[0.048]}\end{array}$ & & & $\begin{array}{c}-0.017 \\
{[0.044]}\end{array}$ \\
\hline Reichsmatrikel contribution & & $\begin{array}{c}-0.234^{* * *} \\
{[0.050]}\end{array}$ & & & $\begin{array}{c}-0.130^{* * * *} \\
{[0.031]}\end{array}$ \\
\hline University & & $\begin{array}{c}0.008 \\
{[0.188]}\end{array}$ & & & $\begin{array}{c}0.081 \\
{[0.161]}\end{array}$ \\
\hline Ecclesiastical & & & $\begin{array}{c}-0.493^{* * *} \\
{[0.129]}\end{array}$ & & $\begin{array}{c}-0.505^{* * *} \\
{[0.098]}\end{array}$ \\
\hline Free Imperial City & & & $\begin{array}{c}0.002 \\
{[0.097]}\end{array}$ & & $\begin{array}{c}0.109 \\
{[0.090]}\end{array}$ \\
\hline Distance to Wittenberg & & & & $\begin{array}{c}-0.130^{* * *} \\
{[0.025]}\end{array}$ & $\begin{array}{c}-0.092^{* *} \\
{[0.037]}\end{array}$ \\
\hline Constant & $\begin{array}{c}-3.365^{* * *} \\
{[1.061]}\end{array}$ & $\begin{array}{c}0.839^{* * *} \\
{[0.064]}\end{array}$ & $\begin{array}{c}0.809^{* * *} \\
{[0.072]}\end{array}$ & $\begin{array}{c}1.121^{* * *} \\
{[0.066]}\end{array}$ & $\begin{array}{l}-1.521 \\
{[1.121]}\end{array}$ \\
\hline N. of observations & 103 & 103 & 103 & 103 & 103 \\
\hline N. of clusters & 88 & 88 & 88 & 88 & 88 \\
\hline R-squared & 0.110 & 0.177 & 0.181 & 0.146 & 0.495 \\
\hline
\end{tabular}

Robust standard errors in brackets, clustered by territorial compound. OLS estimation (linear probability model). ${ }^{* * *}$ significant at $1 \%,{ }^{* *}$ at $5 \%,{ }^{*}$ at $10 \%$. 
Table 3: Adoption of Protestantism-Territory-level regressions, additional controls

\begin{tabular}{|c|c|c|c|c|c|}
\hline \multirow[t]{3}{*}{ Dependent variable } & \multicolumn{5}{|c|}{ Territory Protestant by 1600} \\
\hline & \multirow{2}{*}{$\begin{array}{c}\text { Excluding } \\
\text { Free Imp. Cities } \\
(1)\end{array}$} & \multirow{2}{*}{$\begin{array}{c}\text { Excluding } \\
\text { Free Imp. Cities } \\
\text { and Ecclesiastical } \\
(2)\end{array}$} & \multicolumn{3}{|c|}{$\begin{array}{l}\text { Controlling for Age of the Ruler } \\
\text { (excludes Free Imp. Cities } \\
\text { and Ecclesiastical Territories) }\end{array}$} \\
\hline & & & (3) & (4) & (5) \\
\hline Distance to Wittenberg & $\begin{array}{c}-0.093^{* *} \\
{[0.042]}\end{array}$ & $\begin{array}{c}-0.092^{* *} \\
{[0.044]}\end{array}$ & $\begin{array}{l}-0.077^{*} \\
{[0.043]}\end{array}$ & $\begin{array}{c}-0.094^{* *} \\
{[0.044]}\end{array}$ & $\begin{array}{c}-0.085^{* *} \\
{[0.042]}\end{array}$ \\
\hline Age of the ruler in 1517 & & & $\begin{array}{c}-0.003 \\
{[0.004]}\end{array}$ & & \\
\hline Age of the ruler in 1526 & & & & $\begin{array}{c}0.002 \\
{[0.003]}\end{array}$ & \\
\hline Age of the ruler in 1555 & & & & & $\begin{array}{l}0.005^{* *} \\
{[0.002]}\end{array}$ \\
\hline Constant & $\begin{array}{l}-2.510^{*} \\
{[1.300]}\end{array}$ & $\begin{array}{l}-1.425 \\
{[1.294]}\end{array}$ & $\begin{array}{l}-1.526 \\
{[1.224]}\end{array}$ & $\begin{array}{l}-1.323 \\
{[1.599]}\end{array}$ & $\begin{array}{l}-1.581 \\
{[1.176]}\end{array}$ \\
\hline N. of observations & 66 & 47 & 47 & 47 & 47 \\
\hline N. of clusters & 51 & 33 & 33 & 33 & 33 \\
\hline R-squared & 0.623 & 0.524 & 0.534 & 0.525 & 0.557 \\
\hline
\end{tabular}

Robust standard errors in brackets, clustered by territorial compound. OLS estimation (linear probability model). All columns also include all controls of Table 2, column 5 (coefficients not reported). ${ }^{* * *}$ significant at $1 \%,{ }^{* *}$ at $5 \%,{ }^{*}$ at $10 \%$. 
Table 4: Adoption of Protestantism-City-level regressions

\begin{tabular}{|c|c|c|c|c|c|}
\hline \multirow[t]{3}{*}{ Dependent variable } & \multicolumn{5}{|c|}{ City Protestant by 1600} \\
\hline & Geography & Economy & Institutions & Information & All \\
\hline & (1) & $(2)$ & (3) & (4) & (5) \\
\hline Latitude & $\begin{array}{l}0.115^{* * *} \\
{[0.030]}\end{array}$ & & & & $\begin{array}{l}0.056^{* *} \\
{[0.027]}\end{array}$ \\
\hline Longitude & $\begin{array}{l}0.023^{*} \\
{[0.012]}\end{array}$ & & & & $\begin{array}{l}-0.011 \\
{[0.012]}\end{array}$ \\
\hline River & $\begin{array}{c}-0.133^{* *} \\
{[0.058]}\end{array}$ & & & & $\begin{array}{c}0.008 \\
{[0.042]}\end{array}$ \\
\hline Population in $1500(\log )$ & & $\begin{array}{c}0.006 \\
{[0.022]}\end{array}$ & & & $\begin{array}{c}-0.041 \\
{[0.030]}\end{array}$ \\
\hline Age of the city & & $\begin{array}{c}-0.042^{* *} \\
{[0.016]}\end{array}$ & & & $\begin{array}{l}-0.002 \\
{[0.015]}\end{array}$ \\
\hline Ecclesiastical & & & $\begin{array}{c}-0.530^{* * *} \\
{[0.121]}\end{array}$ & & $\begin{array}{c}-0.526^{* * *} \\
{[0.102]}\end{array}$ \\
\hline Monasteries (p.c.) & & & $\begin{array}{l}-0.035^{*} \\
{[0.018]}\end{array}$ & & $\begin{array}{c}-0.022 \\
{[0.017]}\end{array}$ \\
\hline University & & & $\begin{array}{c}-0.325^{* * *} \\
{[0.107]}\end{array}$ & & $\begin{array}{c}-0.195^{* *} \\
{[0.088]}\end{array}$ \\
\hline Free Imperial City & & & $\begin{array}{c}-0.073 \\
{[0.092]}\end{array}$ & & $\begin{array}{l}0.129^{*} \\
{[0.075]}\end{array}$ \\
\hline Hanseatic & & & $\begin{array}{l}0.200^{* *} \\
{[0.077]}\end{array}$ & & $\begin{array}{c}0.063 \\
{[0.097]}\end{array}$ \\
\hline Distance to Wittenberg & & & & $\begin{array}{c}-0.146^{* * *} \\
{[0.030]}\end{array}$ & $\begin{array}{c}-0.119^{* * *} \\
{[0.029]}\end{array}$ \\
\hline Augustinian Monasteries (p.c.) & & & & $\begin{array}{c}-0.034 \\
{[0.069]}\end{array}$ & $\begin{array}{c}0.037 \\
{[0.069]}\end{array}$ \\
\hline Constant & $\begin{array}{c}-5.263^{* * *} \\
{[1.519]}\end{array}$ & $\begin{array}{l}1.003^{* * *} \\
{[0.125]}\end{array}$ & $\begin{array}{c}0.894^{* * *} \\
{[0.078]}\end{array}$ & $\begin{array}{c}1.206^{* * * *} \\
{[0.066]}\end{array}$ & $\begin{array}{l}-1.486 \\
{[1.496]}\end{array}$ \\
\hline N. of observations & 249 & 249 & 249 & 249 & 249 \\
\hline N. of clusters & 87 & 87 & 87 & 87 & 87 \\
\hline R-squared & 0.234 & 0.110 & 0.269 & 0.232 & 0.516 \\
\hline
\end{tabular}

Robust standard errors in brackets, clustered by territorial compound. OLS estimation (linear probability model). ${ }^{* * *}$ significant at $1 \%,{ }^{* *}$ at $5 \%,{ }^{*}$ at $10 \%$. 
Table 5: Date of introduction of the Reformation

\begin{tabular}{lrr}
\hline Date of introduction of the Reformation & N. of territories & Dist. to Wittenberg \\
\hline \hline Phase 1: until 1532 & 13 & 194.1 \\
Phase 2: $1533^{-1538}$ & 10 & 209.5 \\
Phase 3: $1539-1548$ & 7 & 336.3 \\
Phase 4: $1549-1555$ & 3 & 324.1 \\
Phase 5: $1556-1600$ & 7 & 249.6 \\
Never Protestant & 24 & 352.9 \\
\hline
\end{tabular}


Table 6: Expansion of Protestantism-Territory-level panel regressions

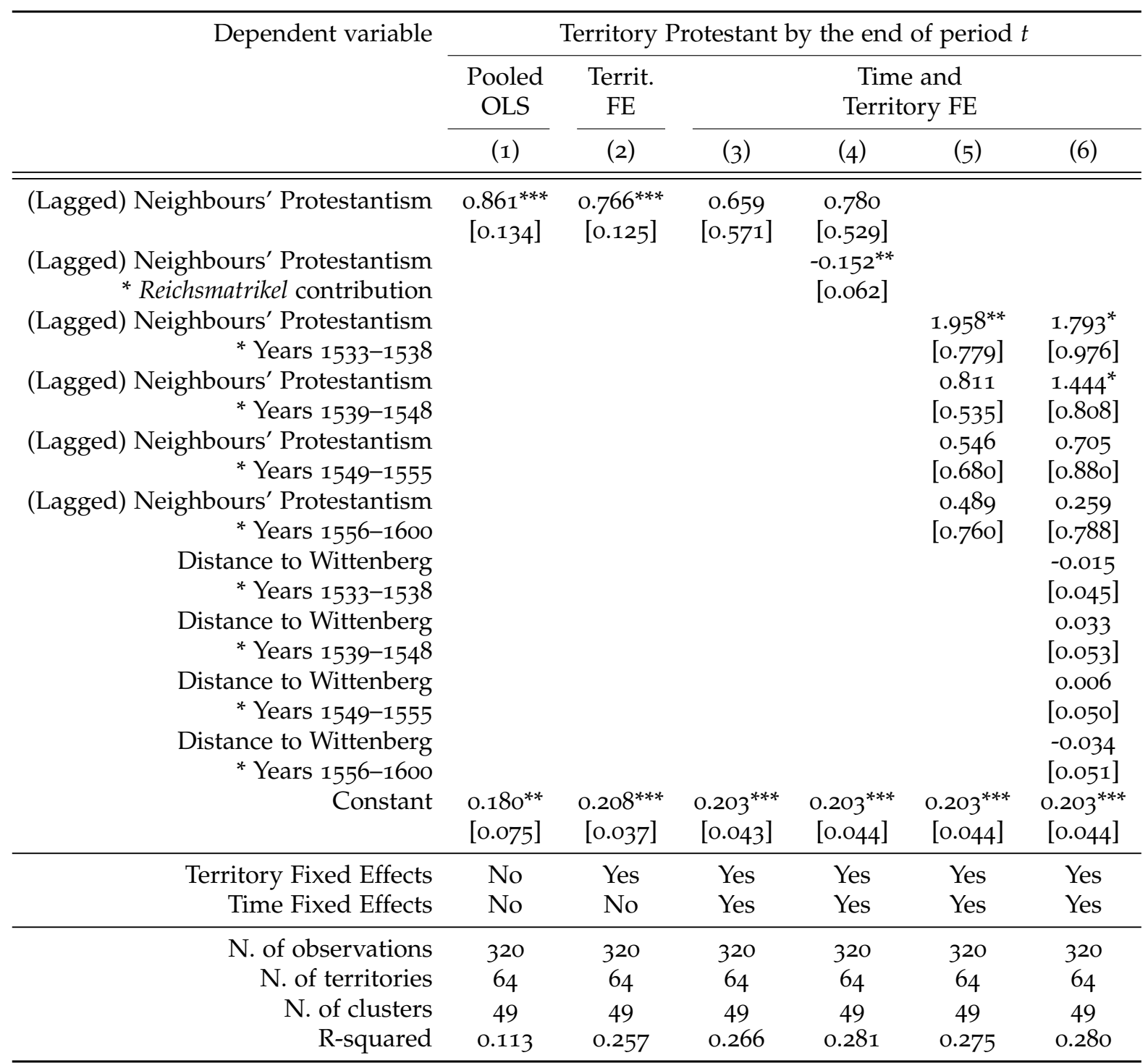

Robust standard errors in brackets, clustered by territorial compound. OLS estimation (linear probability model). ${ }^{* * *}$ significant at $1 \%,{ }^{* *}$ at $5 \%,{ }^{*}$ at $10 \%$. 